\title{
Antiprotozoal activity of Khaya anthotheca, (Welv.) C.D.C. a plant used by chimpanzees for self medication.
}

\author{
C. J. D. Obbo ${ }^{\mathrm{a}, \mathrm{b}^{*}}$, B. Makanga ${ }^{\mathrm{a}}$, D. A Mulholland ${ }^{\mathrm{c}, \mathrm{d}}$, P. H. Coombes ${ }^{\mathrm{c}}$, R. Brun ${ }^{\mathrm{e}}$ \\ a. Department of Zoology, Makerere University, Post Box 7062, Kampala Uganda \\ b. Department of Biological Sciences, Kyambogo University, Post Box 1, Kampala
} Uganda

c. School of Pure and Applied Chemistry, University of Kwazulu-Natal, South Africa.

d. Divisional of Chemical Sciences, Faculty of Health and Medical Sciences, University of Surrey, GU2 7XH, Guildford, United Kingdom

e. Medical Parasitology and Infection Biology Department, Swiss Tropical and Public Health Institute, CH-4002 Basel, Switzerland.

*Corresponing author.

Christopher. J. D. Obbo, Department of Biological Sciences, Faculty of Science, Kyambogo University, Post Box 1, Kyambogo, Kampala, Uganda.

Tel.: +256-41-287 347, +256-41-285001/2; Fax.: +256-41-220464/222643.

E-mail: chrissobbo@yahoo.com

Key Words: Khaya anthotheca, Meliaceae, chimpanzees, self-medication, antiprotozoal, drug-resistance.

\begin{abstract}
Ethnopharmacological relevance:

Khaya species, endemic to Africa and Madagascar, continues to be valuable in indigenous traditional medicine. Their bitter tasting barks are decocted to treat fevers, several febrile conditions, microbial infections and worm infestations. In the Budongo rain forest of Western Uganda, non-human primates, especially chimpanzees and baboons, have been observed to eat the bitter non-nutritious bark and occasionally the seed.
\end{abstract}

Materials and methods: 
Extracts were prepared by sequential fractionation with solvents of increasing polarities and assayed using standard procedures. Bioassay guided purification of the petroleum ether extract by column chromatography yielded three pure limonoids, Grandifolione (1), 7-deacetylkhivorin (2) and 1,3-deacetyldeoxyhavenensin (3). The anti-trypanosomal, anti-leishmanial and anti-plasmodial activities of pure compounds 1 and 2 were evaluated in vitro against Plasmodium falciparum K1, Trypanosoma brucei rhodesiense STIB 900, T. cruzi trypomastigotes (Tulahuen C4), and axenic Leishmania donovani MHOMET67/L82 and for cytotoxicity against L6 rat skeletal myoblast cells, in parallel with standard drugs.

\section{Results:}

Of the four extracts tested, the petroleum ether extract showed activity against $P$. falciparum (IC50 $0.955 \mu \mathrm{g} / \mathrm{ml}$ ) and $T$. b. rhodesiense (IC50 $5.72 \mu \mathrm{g} / \mathrm{ml}$ ). The pure compounds (1) and (2) demonstrated activity against $P$. falciparum (KI strain) and marginal activities against T. brucei brucei, T. b. rhodesiense, T. cruzi and L. donovani.

\section{Conclusion:}

The present study provides evidence justifying the use of Khaya preparations in traditional medicine to treat fevers and microbial infections. The observed anti-protozoal activity of grandifolione and 7-deacetylkhivorin from the seed of $K$. anthotheca further confirms the ethnomedicinal potential of this plant and supports the hypothesis that nonhuman hominids (chimpanzees and baboons) too, eat the bitter bark and seeds for self medication and in general, the use of Khaya plant material for medication by humans in disease endemic tropical areas. The antiprotozoal activity of gradifolione, and, the antitrypanosomal and antileishmanial activities of 7-deacetylkhivorin are reported here for the first time.

\subsection{Introduction.}

Trypanosomiasis and leishmaniasis, long-known but neglected protozoal diseases, continue to afflict poor and disadvantaged tropical communities, with an estimated prevalence of up to 14 million cases for the former, 12 million cases for the later, and an aggregated figure of over 460 million at risk of infection (Brun et al., 2009, Rassi Jr et 
al., 2010, Arun et al., 2011). Malaria alone threatens approximately $40 \%$ of the world's population with estimates of over 800,000 deaths per year (WHO, 2010). While defence and protection against these diseases has majorly depended on drugs, the continuous emergence of resistant parasites has repeatedly compromised the efficacy of each new drug and rendered its use inadequate (Elfawal et al., 2012, Freitas-Junior et al., 2012).

Most disturbing is the limited arsenal of therapeutic agents, some of which are old, highly toxic, prone to resistance, complicated to administer and unaffordable to the poor (Croft et al., 2006, Baker et al., 2012). For malaria treatment, already, reports of emerging resistance to ACT's (White 2010) are extremely disturbing. Consequently there is urgent need for newer, safer and more practical anti-protozoal drugs. In the present study, the anti-protozoal activities of Khaya anthotheca seed were investigated

Khaya anthotheca (Welw.) C.D.C., a member of the family Meliaceae, is a large woody forest tree long exploited as a good timber product. Plants of this family have also been reported to be very important in the ethno-botanic and ethno-pharmacological practices of tropical and subtropical communities, especially Africa, India and Latin America (Mackinnon et al., 1997, Stephen et al., 2009) where species like Cedrela odorata, Carapa quianensis, Swietenia mahagoni and Azadiracta indica have been utilised to treat malaria and other infectious diseases. Several reports indicate that non-human primates, especially chimpanzees and baboons in the wild, also ingest different parts of plants of this family in unusual feeding behaviour (Paterson et al., 2001; Krief et al., 2004). Others have suggested medicinal benefits of such feeding behaviour for parasite control and provided chemical evidence to support the pharmacological roles of secondary metabolites in that respect (Huffman and Seifu, 1989, Ohigashi et al., 1994).

Plants of the family Meliaceae contain limonoids whose dose-dependent antiparasitic activities have been associated with the presence of gedunin, a compound common in this family (Mackinnon et al., 1997). Limonoids were earlier reported to be a possible new source of natural compounds with several beneficial attributes (Lee et al., 2008). This report presents the antitrypanosomal, antileishmanial and antiplasmodial potencies of the crude petroleum ether extract Ka 2-b and two pure compounds, grandifolione (2) and 7deacetykhivorin (1), isolated from $K$. anthotheca seed. 


\section{Materials and Methods}

$K$. anthotheca was selected for this study on the basis of its common use in West African traditional medicine and from documented evidence of its use by primates in Budongo forest in Masindi district, western Uganda. Plant material was identified by Tonny Katende, from Makerere University Herbarium and a voucher specimen (accession number 41660) retained. Mature healthy seeds were collected from the forest bottom in a pure $K$. anthotheca tree plantation at the Budongo Conservation station between the months of December and March and dried in the shade.

\subsection{Extraction and purification Procedure}

The dry pericarp sheath was removed and the air-dried seeds ground into smaller particles in a mortar. Batches of 100 grammes of the seed powder were packed in cellulose thimbles and successively extracted in a soxhlet apparatus with hexane, petroleum ether, dichloromethane and methanol using a modified extraction protocol of Rasoanaivo et al., (1994). The semi-filtered extracts were passed through Whatman filter paper (No. 2) to

remove any debris carried over. Extraction solvents were removed using a Buchi ${ }^{\mathrm{R}}$ rotary evaporator under reduced pressure. The extracts were freeze-dried in a shell freezer system (Labconco ${ }^{\mathrm{R}} / 103 \mathrm{M}$ BAR) at $0^{\circ} \mathrm{C}$. The hexane extract gave viscous colourless oil and the petroleum ether extract separated out into white crystals and a viscous oily portion. The solvent free extracts were kept at room temperature in sample bottles tightly stoppered and sealed with parafilm for future studies. The crystalline petroleum ether extract $(3.22 \mathrm{~g})$ was purified by column chromatography $(6.3 \times 85 \mathrm{~cm})$ over silica gel (70320 mesh, Merck, Darmstadt, Germany) and eluted with dichloromethane: methanol (v/v 48: 2). Further purification was achieved with preparative thin layer chromatography. The compounds were identified as 1. 7-deacetoxykhivorin, $(8.71 \mathrm{mg})$, 2. grandifolione, (19 mg), 3. 1, 3-diacetyldeoxyhavenensin (3.30 mg) (Figure 1) using 1D and 2D NMR spectroscopy and by comparison against literature data (Conolly et al., 1966, Adesogan et al., 1970). The crude petroleum ether extract Ka 2-b and compounds 1 and 2 were screened for antitrypanosomal, antileishmanial and antimalarial activities in vitro. 
Figure 1.
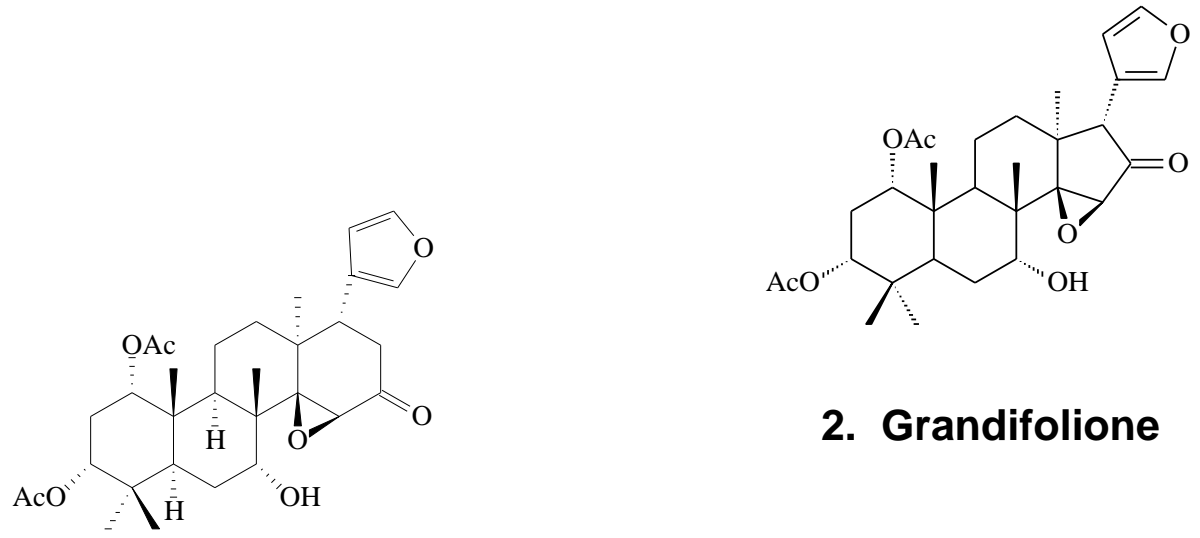

\section{7-deacetylkhivorin}

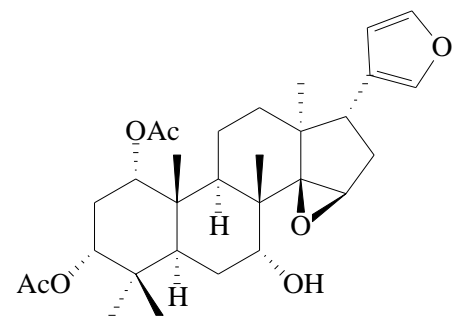

3. 1,3-diacetyldeoxyhavenensin

Figure Caption.

Figure 1: Compounds isolated from the seeds of Khaya anthotheca.

Three tetranorterpenoid limonoid compounds obtained by assay-guided column chromatographic separation of the petroleum ether extract of $K$. anthotheca seed: 1. 7deacetylkhivorin (Mw 544.6), 2. Grandifolione (Mw 528), $3 . \quad 1, \quad 3-$ diacetyldeoxyhavenensin (Mw. 498.4). 


\subsection{In vitro drug sensitivity assays:}

In vitro activities as expressed by inhibitory $50 \%\left(\mathrm{IC}_{50}\right)$ values, were determined for Plasmodium falciparum, Trypanosoma b. rhodesiense, T. cruzi and Leishmania donovani axenic amastigotes as well as for rat skeletal myoblast (L6) cells using the assays as described earlier (Orhan et al., 2010).

The $\mathrm{IC}_{50}$ values were calculated from the sigmoidal inhibition curves using SoftmaxPro software. The selectivity index (SI), ratio of the $\mathrm{IC}_{50}$ for the $\mathrm{L}-6$ cells to the $\mathrm{IC}_{50}$ for the protozoan parasite was calculated for each compound.

\section{Results.}

\begin{tabular}{|c|c|c|c|c|c|}
\hline Drug substance & $\begin{array}{l}\text { T.b. rhodesiense } \\
\mathrm{IC}_{50}\end{array}$ & $\begin{array}{l}\text { T.cruzi } \\
I_{50}\end{array}$ & $\begin{array}{l}\text { L.donovani } \\
\mathrm{IC}_{50}\end{array}$ & $\begin{array}{l}\text { P.falciparum } \\
\mathrm{IC}_{50}\end{array}$ & $\begin{array}{l}\text { Cytotoxicity L6 } \\
I^{I C_{50}}\end{array}$ \\
\hline Crude Ka2-b & 5.72 (17) & $14.51(6)$ & 30 & $0.995(95)$ & 90 \\
\hline Grandifolione & $10.66(4)$ & $20.97(2)$ & $13.31(3)$ & $0.732(64)$ & 44.7 \\
\hline 7-deacetyikhivorin & $16.88(0)$ & $31.82(0.5)$ & $36.71(0.4)$ & $1.370(11)$ & 14.9 \\
\hline Melarsoprol & 0.004 & - & - & - & - \\
\hline Benzinidazole & 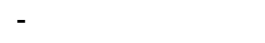 & 0.296 & - & - & - \\
\hline Miltefosine & - & - & 0.156 & - & - \\
\hline Chloroquine & - & - & - & 0.058 & - \\
\hline \multirow[t]{3}{*}{ Podophyllotoxin } & - & - & - & - & 0.005 \\
\hline & \multicolumn{4}{|c|}{$\mathrm{IC}_{50}$ values as $\mu \mathrm{M}$ concentrations. } & \\
\hline & $\mu \mathrm{M}$ & $\mu \mathrm{M}$ & $\mu \mathrm{M}$ & $\mu \mathrm{M}$ & $\mu \mathrm{M}$ \\
\hline Grandifolione & 20.2 & 27.5 & 25.2 & 1.39 & 84.7 \\
\hline 7-deacetylkhivorin & 31.0 & 58.4 & 38.6 & 2.52 & 27.4 \\
\hline Melarsoprol & 0.010 & - & - & - & - \\
\hline Benzinidazole & - & 1.14 & - & - & - \\
\hline Miltefosine & - & - & 0.386 & - & - \\
\hline Chloroquine & - & - & - & 0.112 & - \\
\hline Podophillotoxin & - & - & - & - & 0.012 \\
\hline
\end{tabular}

Table 1: Antiprotozoal activities of limonoids from $K$. anthotheca seed.

$\mathrm{IC}_{50}$ values given as $\mu \mathrm{g} / \mathrm{ml}$ and $\mu \mathrm{M} / \mathrm{ml}$ are shown as the means of two independent assays, (the individual values differed less than $\pm 50 \%$ ). Selectivity indices (SI) appear in brackets.

\subsection{Discussion}


A bioassay guided fractionation of the crude petroleum ether extract yielded three known tetranortriterpenoids or limonoids (Conolly 1966, Adesogan at al., 1970). The crude extract and compounds 1 and 2 showed good antiplasmodial activity against $P$. falciparum (KI strain) and moderate activity against against $T$. rhodesiense, $T$. cruzi and L. donovani. The calculated cytotoxicity indices of the crude extracts and pure compounds were appreciably low. These are known compounds already described but their antiprotozoal activities had not been investigated previously. The anti-trypanosomal, anti-leishmanial and anti-plasmodial activities of grandifolione are reported here for the first time. While antiplasmodial properties of 7-deacetylkhivorin were reported earlier (Agbedahunsi et al., 1998, Bickii et al., 2000), its antileishmanial and antitrypanosomal properties had not yet been studied.

The crude petroleum ether extract of $K$. anthotheca seed demonstrated $\mathrm{IC}_{50}$ activities at $5.7 \mu \mathrm{g} / \mathrm{ml}, 14.51 \mu \mathrm{g} / \mathrm{ml},>30 \mu \mathrm{g} / \mathrm{ml}$ against T.b. rhodesiense, T.cruzi and L. donovani.

A similar trend but at higher doses was observed with the pure limonoids, grandifolione and 7-deacetylkhivorin, showing $\mathrm{IC}_{50}$ activities at $10.66,16.88 \mu \mathrm{g} / \mathrm{ml}$ against $T$. $b$. rhodesiense, 20.97, $31.82 \mu \mathrm{g} / \mathrm{ml}$ against $T$. cruzi, and 13.31, $36.71 \mu \mathrm{g} / \mathrm{ml}$ against $L$. donovani respectively. As is often observed, the pure compounds exhibited lower activities (higher $\mathrm{IC}_{50}$ values) than the crude form of the drug. Compared to 7deacetylkhivorin, grandifolione exhibited correspondingly lower $\mathrm{IC}_{50}$ values against the multi-resistant K1 strain of $P$. falciparum and against the strain of $L$. donovani. Interestingly, both parasites are intracellular protozoans, sequestered in parasitophorous vacuoles.

The crude form of the extract gave a mean antiplasmodial $\mathrm{IC}_{50}$ value of $0.955 \mu \mathrm{g} / \mathrm{ml}$. Pure grandifolione gave an $\mathrm{IC}_{50}=0.732 \mu \mathrm{g} / \mathrm{ml}$, a selectivity index $(\mathrm{SI})=64$, was $6 \mathrm{x}$ more selective than 7-deacetylkhivorin. The antiplasmodial activity of pure grandifolione, was 1.3 times lower than that of the crude extract, being comparable to the activities of trichirubine A and B from T. rubescens (Krief et al., 2004), gedunin (Bickii et al., 2000) and anthethocol (Lee et al., 2008), but 10-40 times less effective as compared to activities of chloroquine, one of the standard antiplasmodial drugs. Pure 7-deacetoxykhivorin gave 
an $\mathrm{IC}_{50}=1.37 \mu \mathrm{g} / \mathrm{ml}$ against $P$. falciparum $\mathrm{K} 1$ strain but remained weak against all other test parasites.

The toxicity of the crude extract at $90 \mu \mathrm{g} / \mathrm{ml}$ was considered negligible. The toxicities of the pure compounds against rat skeletal myoblast cell-line L6 (Kaminsky et al., 1996), at an $\mathrm{IC}_{50}$ of $44.7 \mu \mathrm{g} / \mathrm{ml}$ and $14.9 \mu \mathrm{g} / \mathrm{ml}$ as compared to the toxicity of podophyllotoxin ( $\mathrm{IC}_{50}, 0.005 \mu \mathrm{g} / \mathrm{ml}$ ), were 8940 and 2980 times lower, making these compounds attractive as new sources of biologically active natural products (Singh et al., 1997; Malebo et al., 2009).

\subsection{Conclusions}

This study provides evidence justifying the use of Khaya preparations in traditional medicine to treat fevers, febrile conditions and microbial infections. The two pure limonoids, grandifolione and 7-deacetylkhivorin showed weak activities across the three genera of protozoan parasites, except for Plasmodium falciparum. The observed antiprotozoal activity of grandifolione and 7-deacetylkhivorin from the seed of $K$. anthotheca further confirms the ethnomedicinal potential of this plant and supports the hypothesis that non-human primates (chimpanzees and baboons) too, eat the bitter bark and seeds for self medication. Their low toxicity indices and high selectivity, especially for $P$. falciparum, make them attractive as possible antiplasmodial drug leads. The molecular targets and modes of action in these parasites are worthy of investigation.

\subsection{Acknowledgements}

This study was co-funded by the DAAD, Peoples and Plants Initiative UK and the Uganda National Council for Science and Technology. We thank M. Kaiser, Swiss Tropical and Public Health Institute, Basel, Switzerland, for running the antiprotozoal assays for this study. Special gratitude goes to the Natural Products Group at the School of Pure and Applied Chemistry, University of Kwazulu-Natal, South Africa, for the financial and technical support in the purification and determination of the molecular structures of the pure compounds. More thanks to Prof. B. T. Kiremire in guiding the extraction processes, Dr. W. Olaho-Mukani and Prof. Mike Huffman for sharing relevant information. We acknowledge the CDC, University of Delhi (iaszoology) and Wikipedia free encyclopaedia for permissions to use their images. 


\subsection{REFERENCES.}

Adesogan, E. K., Okorie, D. A. and Taylor, D. A. H., (1970). Limonoids from Khaya anthotheca (Welw.) C. DC. Journal of the Chemical Society C: Organic, 1970: 205-211.

Agbedahunsi, J.M., Elujoba, A. A., Makinde, J. M.and Oduda, A. J. M. (1998). Antimalarial activity of Khaya grandifoliola stem bark. Pharmaceutical Biology, 36: 8-12.

Arun, K. H, Pradip, S., and Syamal, R., (2011). Use of Antimony in the Treatment of Leishmaniasis: Current Status and Future Directions. Molecular Biology International. doi: $10.4061 / 2011 / 571242$.

Baker, N., de Koning H. P., Maser P. and Horn, D., (2013). Drug resistance in African trypanosomiasis: the melarsoprol and pentamidine story. Trends in Parasitology xxx xxxx, Vol. xxx, No. x

Bickii, J., Njifutie, N., Foyere, J. A., Basco, L. K., Ringwald, P. (2000). In vitro antimalarial activity of limonoids from Khaya grandifoliola C.D.C. (Meliaceae). Journal of Ethnopharmacology. 69: 27-33.

Brun, R., Blum, J., Chappius, F. and Burri, C. (2009). Human African Trypanosomiasis. Lancet 375: $148-159$.

Connolly, J. D., Handa, K. L. and Overton, K. H., (1966). Grandifolione: A Novel Tetranortriterpenoid. Chemical Communications, 1966: 867-868.

Croft, S. L., Sundar, S. and Fairlamb, A. H. (2006). Drug Resistance in Leishmaniasis. Clinical Microbiology Reviews 19: 111-126.

Elfawal, M. A., Towler2, MJ., Reich, NG., Golenbock, D., Weathers, P. J., Rich, S. M., (2012). Dried Whole Plant Artemisia annua as an Antimalarial Therapy. PLoS ONE 7(12): e52746.

Freitas-Junior, L. H., Chatelain, E, Kim, H. A.,Siqueira-Neto, J. L., (2012). Visceral Leishmania treatment: What do we have, what do we need and how to deliver it? International Journal for Parasitology: Drugs and Drug Resistance 2: 11-19.

Huffman, M. A., and Seifu, M. (1989). Observations of illness and consumption of a possibly medicinal plant Vernonia amygdalina (Del.), by a wild chimpanzee in the Mahale Mountains National Park, Tanzania. Primates 30: 51-63.

Kaminsky, R., Schmid, C., Brun, R., (1996). An "in vitro selectivity index" for evaluation of cytotoxicity of antitrypanosomal compounds. In Vitro Toxicology 9: 315-324. 
Krief, B., Martin, M. T., Grellier, P., Kasenene, J., Sévenet, T. (2004). Antimicrobial Agents And Chemotherapy. 48: 3196.

Lee, S-E, Kim, M-R, Kim, J-H, Takeoka, G. R., Kim, T-W, Park, B-S. (2008). Antimalarial activity of anthothecol derived from Khaya anthotheca (Meliaceae). Phytomedicine 15: $533-535$.

MacKinnon, S., Durst, T., Arnason, J. T., Angerhofer, C., Pezzuto, J., Sanchez-Vindas, P. E., Poveda, L. J., Gbeassor, M., (1997). Antimalarial activity of tropical Meliaceae extracts and gedunin derivatives. Journal of Natural Products. 60: 336-341.

Malebo, H. M., Wenzler, T., Cal, M., Swaleh, S. A. M., Omolo, M. O., Hassanali, A., Sequin, A., Hamburger, M., Brun, R. and Ndiege, I. O. (2009). Antiplasmodial, antitrypanosomal, anti-leishmanial and cytotoxicity activity of selected Tanzanian medicinal plants. Tanzania Journal of Health Research, 11: 226-234.

Ohigashi, H., Huffman, M. A., Izutsu, D., Koshimizu, K., Kawanaka, M., Sugiyama, H., Kirby, G. C., Warhust, D. C., Phillipson, J. D., Timon-David, P., Delmas, F., Elias, R. and Balansard, G., (1994). Towards the Chemical Ecology of Medicinal Plant Use in Chimpanzees: The case of Vernonia amygdalina, a Plant Used by Wild Chimanzees Possibly for Parasite-related Diseases. Journal of Chemical Ecology, 20: 541-553.

Orhan I, Sener B, Kaiser M, Brun R, Tasdemir D.(2010). Inhibitory activity of marine spongederived natural products against parasitic protozoa. Marine Drugs. 8:47-58.

Paterson, J. D., Facchini, P. and Teichroeb, J. A., (2001). Phytochemicals and energy, Khaya bark consumption by Budongo primates. The $18^{\text {th }}$ Congress of the International Primaatology society. Primates in the new millennium. Abstracts and Programes 2001. Adelaid: IPS p. 59.

Rassi, A. Jr., Rassi A., Marin-Neto J. A. (2010). Chagas disease. Lancet. 375:1388-402.

Rasoanaivo, P., Ratsmamanga-Urveg, S., Milijaona, R., Rafatro, H., Rakoto-Ratsimamanga, A., Galeffi, C. and Nicoletti, M., (1994). In vitro and in vivo chloroquine-potentiating action of Strychnos myrtoides akkaloids against chloroquine-resistant strains of Plasmodium malaria. Planta Medica, 60: 13-16.

Singh, M., Khokhar, S., Malik, S., Singh, R., (1997). Evaluation of neem (Azadirachta indica A. Juss) extracts against American bollworm, Helicoverpa armigera (Hubner). Journal of Agricultural and Food Chemistry. 45: 3262-3268. 
Stephen, U. A., Abiodun, F., Osahon, O and Ewaen, E. (2009). Phytochemical Analysis and antibacterial Activity of Khaya grandifoliola stem Bark. Journal of Biological Sciences 9: 63-67.

White, N. J., (2010). Artemisinin resistance-the clock is ticking. Lancet; 376: 2051-52.

World Malaria report (WMR 2009). www.who.int/malaria/world_malaria_report_2009/en/

WHO (2010) World Malaria Report. Geneva, World Health Organization. 